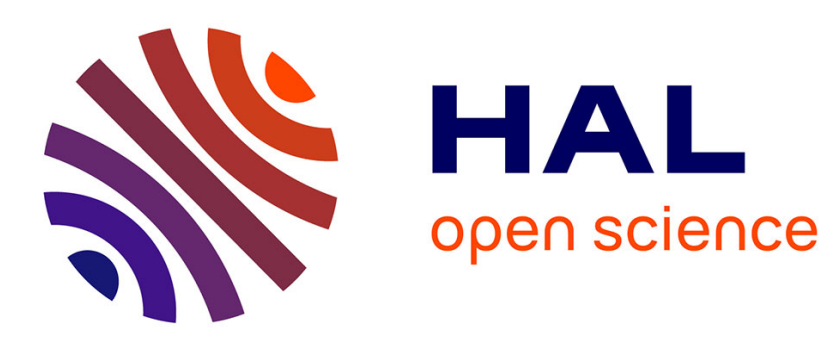

\title{
Effect of different plasticizers on the mechanical and surface properties of wheat gliadin films
}

\author{
A.C. Sanchez, Yves Popineau, Cécile Mangavel, Colette Larré
}

\section{To cite this version:}

A.C. Sanchez, Yves Popineau, Cécile Mangavel, Colette Larré. Effect of different plasticizers on the mechanical and surface properties of wheat gliadin films. Journal of Agricultural and Food Chemistry, 1998, 46 (11), pp.4539-4544. hal-02695277

\section{HAL Id: hal-02695277 \\ https://hal.inrae.fr/hal-02695277}

Submitted on 1 Jun 2020

HAL is a multi-disciplinary open access archive for the deposit and dissemination of scientific research documents, whether they are published or not. The documents may come from teaching and research institutions in France or abroad, or from public or private research centers.
L'archive ouverte pluridisciplinaire HAL, est destinée au dépôt et à la diffusion de documents scientifiques de niveau recherche, publiés ou non, émanant des établissements d'enseignement et de recherche français ou étrangers, des laboratoires publics ou privés. 


\section{Effect of Different Plasticizers on the Mechanical and Surface Properties of Wheat Gliadin Films}

\section{Ana Cristina Sánchez, Yves Popineau, Cécile Mangavel, Colette Larré, and Jacques Guéguen}

Unité de Biochimie et Technologie des Protéines, Institut National de

la Recherche Agronomique, rue de la Géraudière, B.P. 71627, 44316 Nantes Cedex 3, France
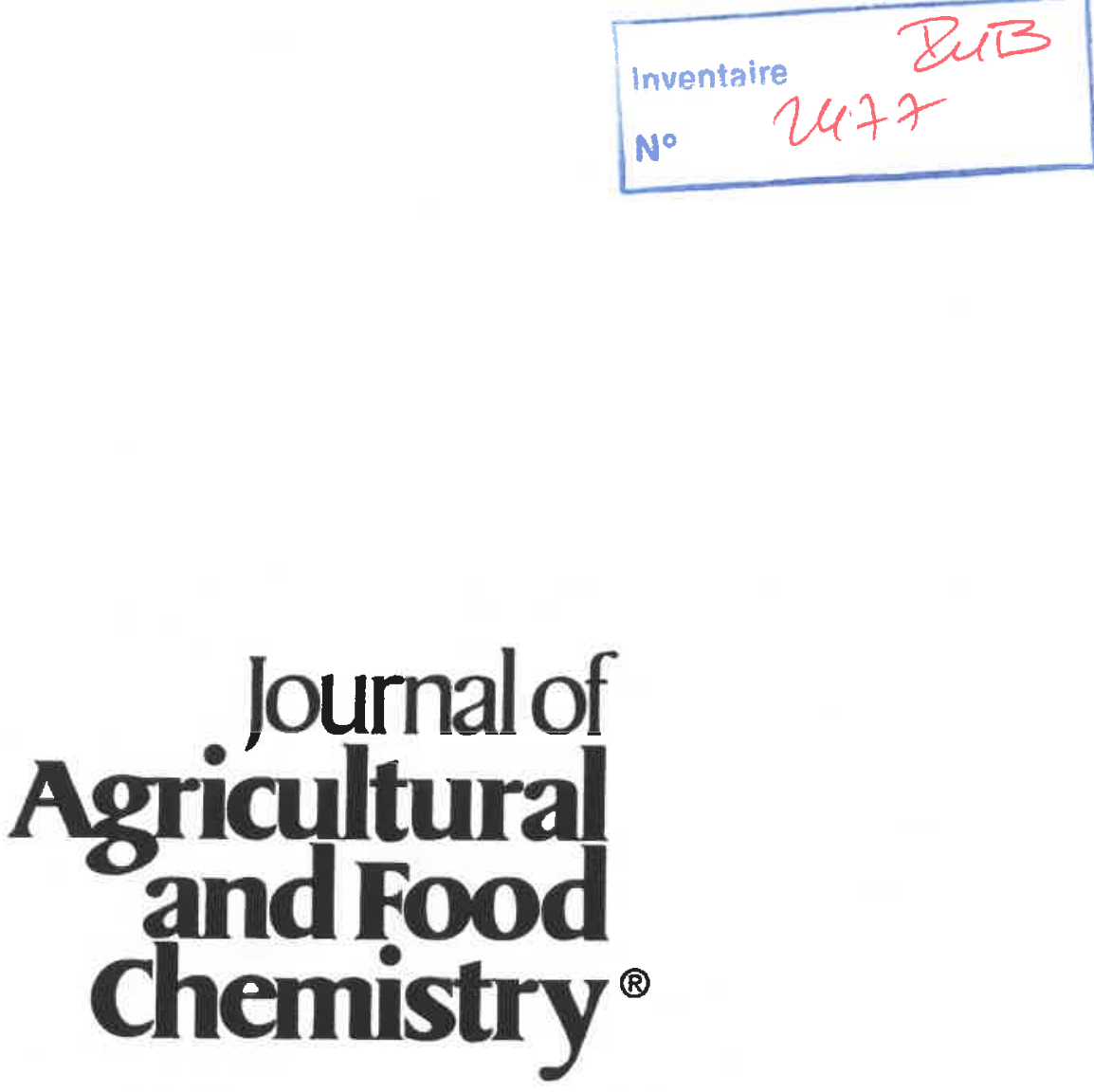

Reprinted from

Volume 46, Number 11, Pages 4539-4544 


\title{
Effect of Different Plasticizers on the Mechanical and Surface Properties of Wheat Gliadin Films
}

\author{
Ana Cristina Sánchez, Yves Popineau, * Cécile Mangavel, Colette Larré, and Jacques Guéguen \\ Unité de Biochimie et Technologie des Protéines, Institut National de la Recherche Agronomique, \\ rue de la Géraudière, B.P. 71627, 44316 Nantes Cedex 3, France
}

\begin{abstract}
Films were prepared by casting alkaline solutions of gliadin, a major wheat storage protein fraction. Their compositions and mechanical and surface properties were analyzed. Five polyols of the ethylene glycol series and glycerol were compared as plasticizers. The plasticized film-forming solutions exhibited viscosities almost independent of shear rate. Glycerol-containing protein solutions had, however, a higher viscosity than others. After drying, concentrations of plasticizers in films were explained mainly, but not uniquely, by their volatility. At equal concentrations in films, glycerol and tetraethylene glycol were more efficient than the other plasticizers studied. A wide range of elongation $(10-600 \%)$ was obtained when the plasticizer contents were varied, but the tensile strength $(2-12 \mathrm{MPa})$ was always lower than that of usual synthetic polymer films. A negative relationship, independent of the plasticizing molecules used, was found between tensile strength and elongation at break of gliadin films. Surface hydrophobicity of films was high and no influence of plasticizers was observed.
\end{abstract}

Keywords: Film; gliadins; wheat; plasticizer; polyols

\section{INTRODUCTION}

In recent years, environmental concerns have increased the interest in using renewable agricultural resources to prepare packaging materials. Most efforts were originally devoted to cellulose and starch. These polysaccharides are of prime interest as biopolymers because of their availability and rather low cost. However, the resulting biomaterials show some drawbacks, such as great water sensitivity and low elasticity, even after chemical modification, which limit their uses. Thus, it is necessary to investigate the film-forming potential of other biopolymers. Among proteins, some have properties desirable in the preparation of biomaterials, such as ability to form fibers or network, plasticity, and elasticity. This might explain the increasing interest for using commercially available proteins to prepare biomaterials, especially films. Biopolymers were used to prepare edible films (Kester and Fennema, 1986; Torres, 1994; Krochta and De MulderJohnston, 1997). The film properties of different plant proteins were studied: soy proteins (Gennadios and Weller, 1991; Gennadios et al., 1993b; Stuchell and Krochta, 1994; Kunte et al., 1997), corn zein (Gennadios and Weller, 1990; Gennadios et al., 1993a; Yamada et al., 1995; Parris and Coffin, 1997), wheat gluten (Gontard et al., 1992, 1993; Gennadios et al., 1993c,d), sorghum kafirin (Buffo et al., 1997), rice bran and peanut protein (Gennadios et al., 1997), cottonseed protein (Marquié et al., 1995), and pea protein (Guéguen et al., 1995; Viroben et al., 1995).

Proteins associate by intermolecular interactions (electrostatic, hydrogen, and hydrophobic). Protein structure and conformation influence the intermolecular interactions necessary for formation of a gel-type net-

* Author to whom correspondence should be addressed (email popineau@nantes.inra.fr; fax +3324067 50 25). work, which is then dehydrated (Miller and Krochta, 1997). The strength of protein-protein and proteinwater interactions determines the properties of the materials and can be controlled by means of the filmforming conditions and by the presence of a plasticizer. Plasticizers decrease the protein interactions and increase polymer chain mobility and intermolecular spacing, decreasing also the glass transition temperature of proteins. A plasticizer is required to avoid brittleness and to increase the flexibility of the films. The plasticizers must have low molecular weights, high boiling points, compatibility with the polymers, and solubility in the solvent (Banker, 1966). Oligosaccharides, polyols (polyhydric alcohols), and lipids are different types of plasticizers, and the most frequently used is glycerol. The type and concentration of plasticizer influence properties of protein films (Gennadios et al., 1993d; McHugh et al., 1994; McHugh and Krotcha, 1994; Cuq et al., 1997b; Guéguen et al., 1998).

Because the raw material is produced in large amounts at a reasonable price, several studies were done on wheat gluten films (Gennadios and Weller, 1990; Gontard et al., 1992, 1993; Gennadios et al., 1993a-d; Cherian et al., 1995; Herald et al., 1995; Gontard and Ring, 1996; Ali et al., 1997; Rayas et al., 1997). By contrast, there have been only a few descriptions of films made of gliadins, the monomeric fraction of glutamineand proline-rich wheat storage proteins (Okamoto, 1978; Gontard, 1991). Because gliadin is less complex than the polydisperse protein mixture composing gluten and contains no contaminating starch and few lipids, the aim of the present work was to study gliadin films, looking especially at the influence of plasticizers on the rheological properties of the film-forming solutions and on the surface and mechanical properties of the films. Glycerol and polyols from the ethylene glycol series were 
chosen as plasticizers, regardless of their edibility, because protein films should be intended for nonfood uses.

\section{MATERIALS AND METHODS}

Materials. A gliadin-rich fraction (86.4\% proteins, $\mathrm{N} \times \mathbf{5 . 7}$ ) was obtained by fractionation of industrial vital gluten (Roquette, Lestrem, France) at the pilot scale, following the method of Bérot et al. (1994), based on an acetic acid extraction, followed by centrifugation and ultrafiltration of the supernatant. The gliadin retentate was spray-dried.

Ethylene glycol (EG), diethylene glycol (DEG), triethylene glycol (TEG), tetraethylene glycol (TEEG), diethylene glycolmonomethyl ether (DEGMET), as a more hydrophobic derivative of DEG, and glycerol (GLY) were purchased from Fluka or Sigma. All other reagents and chemicals were of analytical grade.

Preparation of Films. Gliadins were dispersed into $0.1 \mathrm{~N}$ $\mathrm{NaOH}$ solution by using a Polytron homogenizer $(25000 \mathrm{rpm}$ for $90 \mathrm{~s}$ ). A second mixing ( $25000 \mathrm{rpm}$ for $60 \mathrm{~s}$ ) was performed after a rest of $60 \mathrm{~s}$ to limit heating of the sample. After addition of the plasticizer (plasticizer/protein ratios $=0.26-$ $0.51 \mathrm{w} / \mathrm{w})$, the mixture was stirred three times $(25000 \mathrm{rpm}$ for 90,60 , and $60 \mathrm{~s}$ ) with rests of $60 \mathrm{~s}$ between each stirring, and then centrifuged $(115 \mathrm{~g}, 30 \mathrm{~min})$ to eliminate the air bubbles. The protein content of the film-forming solution was $16 \%(\mathrm{w} / \mathrm{w})$ and its $\mathrm{pH} 11$. Alkaline conditions for gliadin filmforming solutions were chosen here because Gennadios et al. (1993b) showed that casting films of gluten proteins at alkaline $\mathrm{pH}$ resulted in higher tensile strengths than at acidic casting conditions with no significant differences in elongation. The deaerated solution was spread over a glass plate $(260 \times 150$ $\times 0.5 \mathrm{~mm}$ ) covered with a Gel Bond sheet (a polyester film) to help the peeling of the dried film and then dried in a ventilated oven at $70^{\circ} \mathrm{C}$ during $1 \mathrm{~h}$. The gliadin film was peeled off from the plate and equilibrated for 3 days in a cabinet under standard conditions of temperature $\left(20^{\circ} \mathrm{C}\right)$ and relative humidity ( $\mathrm{RH}=60 \%$, produced by a saturated solution of sodium bromide). The gliadin films were in all cases transparent, with a light yellowish color.

Loss of Weight. The loss of weight of the films was determined by weight difference $( \pm 0.1 \mathrm{mg})$ of the film before and after drying for $1 \mathrm{~h}$ at $70^{\circ} \mathrm{C}$.

Plasticizer Content. The residual amount of plasticizer in films was determined by high-performance liquid chromatography. Film samples $(500 \mathrm{mg})$ were extracted twice with deionized water $(25 \mathrm{~mL}$ ) for 60 and $30 \mathrm{~min}$. The supernatant was applied on an ion-exchange column (Shandon $\mathrm{Cl}^{-} \mathrm{MCa}$ ) heated at $60{ }^{\circ} \mathrm{C}$. The plasticizer was eluted by water and detected by a differential refractometer (Jobin-Yvon). The concentration was calculated by reference to a calibration curve of the same plasticizer.

Residual Water. Film samples $(500 \mathrm{mg}$ ) were dried under reduced pressure during $24 \mathrm{~h}$ in a desiccator containing $\mathrm{P}_{2} \mathrm{O}_{5}$, because preliminary assays had shown that no change of weight occurred after this time. The water content in films was determined from weight difference of the samples before and after drying.

Viscosity Measurements of Film-Forming Solutions. Flow curves of film-forming solutions, plasticizer solutions, and protein solutions were recorded at $20^{\circ} \mathrm{C}$ at shear rates $0-100$ $\mathbf{s}^{-1}$ with a RFS2 Rheometrics rheometer, using a coaxial cylinder device. Viscosity was calculated by dividing shear stress by shear rate. For each condition, two solutions were analyzed in duplicate.

Mechanical Properties. Mechanical properties of films were investigated on film specimens of $75 \mathrm{~mm}$ length with a dumbbell shape (5A type, ISO 527-2 standard). Five replicates were tested for each film assay. Film thickness was measured at five points with a hand-held micrometer (Morton-Blet, Prolabo France; range of measurements $=1-1000 \mu \mathrm{m}$ ). Elongation at break (EL) and tensile strength (TS) were measured at $20^{\circ} \mathrm{C}$ with a traction-compression device (model

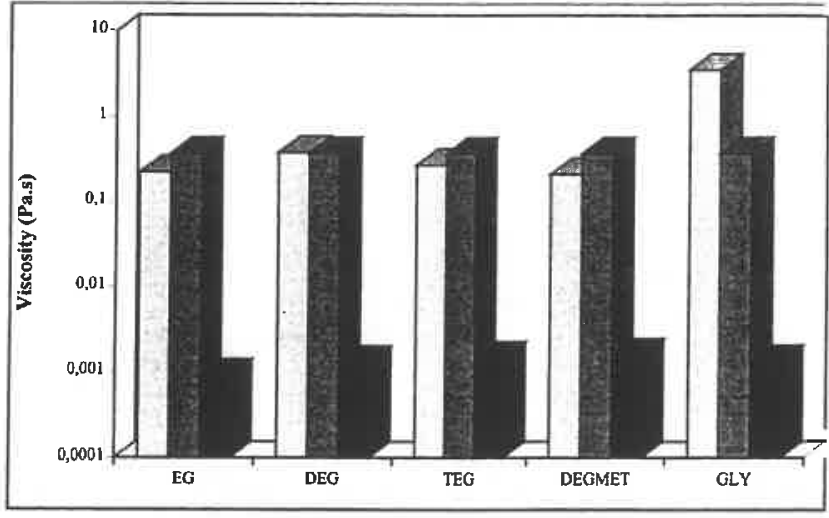

Figure 1. Viscosity of film-forming solutions at $5 \mathrm{~s}^{-1}$ shear rate, in the presence of different plasticizers. For reference are also shown the viscosities of gliadin solutions and plasticizer solutions at the same concentrations as in the film-forming solutions. Bars represent, from left to right within each grouping, film-forming solution, protein solution, and plasticizer solution.

DY34, Adamel-Lhomargy Testing Instrument, Ivry, France) equipped with a $10 \mathrm{~N}$ load cell. Initial grip separation was set at $50 \mathrm{~mm}$, while cross-head speed was set at $20 \mathrm{~mm} \mathrm{~min}^{-1}$ TS was calculated by dividing maximum stress by the crosssectional area of the film and EL was expressed in percentage of the initial length of the elongating part of the specimen (20 $\mathrm{mm}$ ).

Surface Hydrophobicity. Surface hydrophobicity of films was evaluated through contact angle measurement using an image analysis system DigiDrop, GBX. After a drop of deionized purified water (Milli- $Q$ system) was placed above the film, the angle of the tangent to the basis of the drop (contact angle) was measured and expressed in degrees.

Statistics. The results were compared by analysis of variance and Duncan's multiple-range test. Statgraphics Plus software was used for this purpose.

\section{RESULTS AND DISCUSSION}

Viscosity of Film-Forming Solutions. The addition of EG, DEG, TEG, and DEGMET to protein solutions (plasticizer/protein ratio $=0.37 \mathrm{w} / \mathrm{w}$ ) decreased the viscosity, and no large difference was observed among these plasticizers. Only glycerol increased considerably the viscosity, although the viscosity of the glycerol solution alone was not higher than that of other plasticizers (Figure 1). In the absence of plasticizer, the viscosity of protein solutions was decreasing with increasing shear rate. In the presence of plasticizer, viscosity was almost independent of shear rate (Figure 2). The differences between film-forming and protein solutions were mainly observed at low shear rate. The lower viscosity of film-forming solutions at $0.1 \mathrm{~s}^{-1}$ might be interpreted as a weakening of protein-protein interactions due to the plasticizer. Higher shear rates destroyed these interactions, resulting in similar behaviors in the presence as in the absence of plasticizer. Mate and Krochta (1996) described the same shearthinning behavior of film-forming solutions of whey protein as we observed for gliadins (Figure 2). Viscosities of gliadin film-forming solutions were in the range indicated by Cuq et al. (1995) as convenient for an easy film casting, that is, $<700 \mathrm{mPa} \cdot \mathrm{s}$.

Reproducibility of Film Preparation. Three filmforming solutions were prepared using diethylene glycol as plasticizer (plasticizer/protein ratio $=0.37 \mathrm{w} / \mathrm{w}$ ), and two films were cast from each one. Results of all tests performed are shown in Table 1. Evaporation of water 


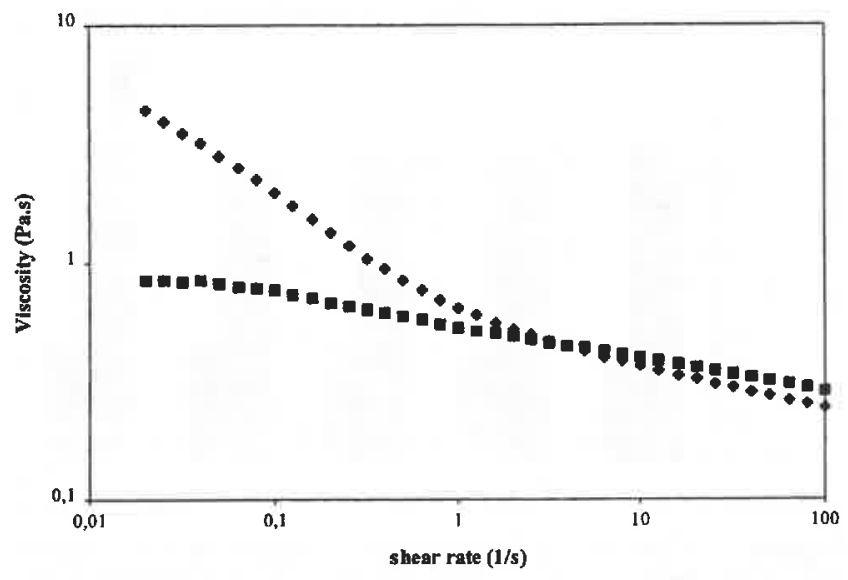

Figure 2. Viscosities as a function of the shear rate of a gliadin solution $(\downarrow)$ and of a film-forming solution in the presence of DEG (a). Protein concentration in film-forming solutions was $16 \%$, and the plasticizer/protein ratio was 0.37 .

and plasticizer during drying was very reproducible. Film thickness after drying was more variable. The higher variability of TS measurements was possibly due to thickness variability, although Cuq et al. (1996) reported that film thickness had no influence on TS of protein films. EL showed less variability. In all of the experiments reported below, four films were prepared from two film-forming solutions and the numbers of analyses per film were those indicated in Table 1.

Effect of the Plasticizer Chemical Structure. Films with the Same Weight of Plasticizer in the FilmForming Solution. All films were prepared with a plasticizer/protein ratio of $0.37(\mathrm{w} / \mathrm{w})$ and were dried at the same conditions. Only the water content of the film with DEGMET was significantly different from the others, but all of the films differed significantly in their plasticizer contents (Table 2). No glycerol [boiling point (bp) $\left.=290^{\circ} \mathrm{C}\right]$ was evaporated, but $66 \%$ of the DEGMET (bp $=193^{\circ} \mathrm{C}$ ) was lost. Losses for EG $\left(b p=198^{\circ} \mathrm{C}\right.$ ), DEG $\left(\mathrm{bp}=244^{\circ} \mathrm{C}\right)$, TEG $\left(\mathrm{bp}=287^{\circ} \mathrm{C}\right)$, and TEEG (bp $=307{ }^{\circ} \mathrm{C}$ ) were $46,23,13$, and $17 \%$, respectively. Considering that initial contents were the same for all plasticizers, these differences could be explained partially by their different boiling points. However, this is not the sole explanation, because more TEG and
TEEG than GLY was lost, although they have similar or even higher boiling points; interactions between glycerol and proteins cannot be excluded. Thus, to maintain equal contents of plasticizer in films for comparison, specific drying conditions must be adapted for each plasticizer or plasticizer contents of filmforming solutions must be adjusted.

Tensile strength and elongation at break of films are shown in Table 2. It was not possible to characterize films plasticized with glycerol, because they were very sticky and impossible to peel off from the glass plate. This behavior was due to an excessive content of plasticizer, because experiments performed later with $20 \%$ of glycerol resulted in films easy to manipulate. The stress-elongation curves were in all cases not linear, indicating a plastic behavior. TS of films were between 1.6 and 11.3 $\mathrm{MPa}$ and EL between 3.8 and $557 \%$. Smaller TS values corresponded to higher EL values. Because the residual contents of each plasticizer were different, differences in mechanical properties could not be attributed to the structure of the plasticizer molecules rather than to their concentrations in the films. Volatility must be taken into account in the choice of a plasticizer, because it influences the cost and the safety of the process and the stability of film properties with aging.

Protein films similar to polysaccharide films are known for their hydrophilic character, but the gliadin films exhibited contact angles between $85^{\circ}$ and $105^{\circ}$. The angle increased with the number of carbons in the EG series, but plasticizer contents varied, too. Nevertheless, contact angles of pea protein films were in the range of $14-40^{\circ}$ (Guéguen et al., 1998). This means that gliadin films were less readily wetted, suggesting a higher surface hydrophobicity, which can be related to the water insolubility of gluten proteins. Indeed, their values of contact angle were similar to those observed currently with polystyrene or poly(tetrafluoroethylene) (Extrand and Kumagai, 1997). In contrast with synthetic polymer films, angles on gliadin films decreased rapidly with contact time (not shown), suggesting a rapid change of surface properties.

Films with the Same Amount of Residual Plasticizer. To compare with confidence the effects of the plasticizer molecules on hydrophobicity and mechanical properties

Table 1. Reproducibility of the Different Measures on Films Prepared with DEG ${ }^{\alpha}$

\begin{tabular}{llcccccc}
\hline & $\begin{array}{c}\text { loss of } \\
\text { wt }(\%)\end{array}$ & $\begin{array}{c}\text { residual } \\
\text { water }(\%)\end{array}$ & $\begin{array}{c}\text { plasticizer } \\
\text { content }(\%)\end{array}$ & $\begin{array}{c}\text { thickness } \\
(\mu \mathrm{m})\end{array}$ & $\begin{array}{c}\text { contact } \\
\text { angle (deg) }\end{array}$ & $\begin{array}{c}\text { TS } \\
(\mathrm{MPa})\end{array}$ & $\begin{array}{c}\mathrm{EL} \\
(\%)\end{array}$ \\
\hline no. of films & 6 & 6 & 6 & 6 & 6 & 6 & 6 \\
repeat/film & 1 & 2 & 2 & 25 & 5 & 5 \\
av & 76.9 & 9.5 & 20.0 & 67.5 & 90.4 & 5 \\
SD & 1.5 & 0.9 & 0.6 & 8.5 & 3.6 & 2.6 & 0.2 \\
CV (\%) & 1.9 & 1.0 & 3.0 & 12.5 & 4.0 & 32 \\
\end{tabular}

a Protein concentration in film-forming solutions was $16 \%$ and plasticizer/protein ratio was 0.37 .

Table 2. Residual Water and Plasticizer Contents and Mechanical and Surface Properties of Films Prepared with the Same Initial Contents of Different Plasticizers in the Film-Forming Solution

\begin{tabular}{|c|c|c|c|c|c|}
\hline plasticizer & $\begin{array}{c}\text { residual } \\
\text { water }(\%)\end{array}$ & $\begin{array}{l}\text { plasticizer } \\
\text { content }(\%)\end{array}$ & $\begin{array}{c}\mathrm{TS} \\
(\mathrm{MPa})\end{array}$ & EL (\%) & $\begin{array}{c}\text { contact } \\
\text { angle (deg) }\end{array}$ \\
\hline $\begin{array}{l}\text { EG } \\
\text { DEG } \\
\text { TEG } \\
\text { TEEG } \\
\text { DEGMET } \\
\text { GLY }\end{array}$ & $\begin{array}{c}10.3(1.5)^{a} \mathrm{~d}^{b} \\
9.5(0.9) \mathrm{b} \\
9.5(1.4) \mathrm{b} \\
9.8(0.3) \mathrm{c} \\
7.2(0.05) \mathrm{a} \\
9.0(2.2) \mathrm{b}\end{array}$ & $\begin{array}{l}14.6(1.3) \mathrm{b} \\
20.0(0.6) \mathrm{c} \\
23.6(1.5) \mathrm{e} \\
22.3(1.3) \mathrm{d} \\
10.0(1.9) \mathrm{a} \\
28.1(0.8) \mathrm{f}\end{array}$ & $\begin{array}{l}4.1(1.2) \mathrm{b} \\
2.5(0.2) \mathrm{ab} \\
2.8(0.7) \mathrm{ab} \\
1.6(0.2) \mathrm{a} \\
11.3(5.2) \mathrm{c} \\
\text { nd }^{\mathrm{c}}\end{array}$ & $\begin{array}{l}243(47) \mathrm{b} \\
479(32) \mathrm{c} \\
504(112) \mathrm{c} \\
557(38) \mathrm{d} \\
3.8(1.5) \mathrm{a} \\
\text { nd }\end{array}$ & $\begin{array}{c}85(4) \mathrm{a} \\
90(4) \mathrm{b} \\
94(5) \mathrm{c} \\
105(4) \mathrm{e} \\
95(2) \mathrm{c} \\
99(11) \mathrm{d}\end{array}$ \\
\hline
\end{tabular}

${ }^{a}$ Values in parentheses indicate standard deviation. ${ }^{b}$ Values in one column followed by the same letter were not significantly different at the risk $5.0 \%$ (analysis of variance and Duncan's multiple-range test). ${ }^{c}$ nd, not determined. 
Table 3. Residual Water and Plasticizer Contents and Mechanical and Surface Properties of Films Prepared with the Same Residual Contents of Different Plasticizers

\begin{tabular}{|c|c|c|c|c|c|c|}
\hline plasticizer & plasticizer/protein ratio & $\begin{array}{c}\text { residual } \\
\text { water }(\%)\end{array}$ & $\begin{array}{c}\text { residual } \\
\text { plasticizer }(\%)\end{array}$ & TS (MPa) & EL $(\%)$ & $\begin{array}{c}\text { contact } \\
\text { angle (deg) }\end{array}$ \\
\hline $\mathrm{EC}$ & 0.51 & $9.6(1.3)^{a} \mathrm{l}^{b}$ & $21.5(2.4) b c$ & $2.7(0.4) \mathrm{b}$ & $393(32)$ a & $90(\overline{7}) \mathrm{a}$ \\
\hline DEG & 0.37 & $9.5(0.9) \mathrm{b}$ & $20.0(0.6) \mathrm{ab}$ & $2.5(0.2) \mathrm{b}$ & $479(32) \mathrm{b}$ & $90(4) \mathrm{a}$ \\
\hline TEG & 0.31 & $7.6(0.4) \mathrm{a}$ & $19.4(1.6) \mathrm{a}$ & $3(1.1) c$ & $423(11) \mathrm{ab}$ & $100(2) b$ \\
\hline TEEG & 0.33 & $10.3(0.1) \mathrm{c}$ & $22.2(0.7) \mathrm{c}$ & $1.5(0.4) \mathrm{a}$ & $595(120) \mathrm{c}$ & $112(7) d$ \\
\hline GLY & 0.26 & $9.4(0.1) \mathrm{b}$ & $19.0(2.8) \mathrm{a}$ & $1.8(0.9) \mathrm{a}$ & $562(120) \mathrm{c}$ & $104(3) \mathrm{c}$ \\
\hline
\end{tabular}

${ }^{a}$ Values in parentheses indicate standard deviation. ${ }^{b}$ Values in one column followed by the same letter were not significantly different at the risk $5.0 \%$ (analysis of variance and Duncan's multiple-range test).

Table 4. Residual Water and Plasticizer Contents and Mechanical and Surface Properties of Films Prepared with Different Residual Contents of DEG and DEGMET

\begin{tabular}{|c|c|c|c|c|c|}
\hline plasticizer & $\begin{array}{c}\text { residual } \\
\text { plasticizer }(\%)\end{array}$ & $\begin{array}{c}\text { residual } \\
\text { water }(\%)\end{array}$ & TS (MPa) & EL (\%) & $\begin{array}{c}\text { contact } \\
\text { angle (deg) }\end{array}$ \\
\hline \multirow[t]{4}{*}{ DEG } & 14.3 & $8.8(0.6)^{a} b^{b}$ & $5.2(0.9) \mathrm{d}$ & $188(78) a$ & $97(3) b$ \\
\hline & 17.1 & $9.6(0.5) \mathrm{c}$ & $4.4(0.2) \mathrm{c}$ & $209(73)$ a & $101(3) \mathrm{c}$ \\
\hline & 18.5 & $8.3(0.2) \mathrm{a}$ & $3.8(0.3) b$ & $362(69) \mathrm{b}$ & $98(6) b$ \\
\hline & 20.0 & $9.5(0.9) \mathrm{c}$ & $2.5(0.2) \mathrm{a}$ & $490(32) c$ & $90(3) a$ \\
\hline \multirow[t]{3}{*}{ DEGMET } & 10.0 & $7.2(0.5) \mathrm{b}$ & $11.3(5.2) \mathrm{b}$ & $3.8(1.5) \mathrm{a}$ & $95(2) \mathrm{b}$ \\
\hline & 12.5 & $7.7(0.4) \mathrm{b}$ & 8.5 (5) ab & $195(65) \mathrm{b}$ & $97(3) b$ \\
\hline & 14.9 & $5.4(0.4) \mathrm{a}$ & $3.8(0.9) \mathrm{a}$ & $291(20) \mathrm{c}$ & $91(7)$ a \\
\hline
\end{tabular}

${ }^{a}$ Values in parentheses indicate standard deviation. ${ }^{b}$ Values in one column followed by the same letter were not significantly different at the risk $5.0 \%$ (analysis of variance and Duncan's multiple-range test).

of films, we strove to prepare films containing the same amounts of residual plasticizer (20\%). The weight of plasticizer added to film-forming solutions was estimated by assuming that the residual content was directly proportional to initial amounts for fixed drying conditions. It was impossible to prepare a film with DEGMET because a phase separation occurred in the film-forming solution for concentrations lower than that required. With other plasticizers, the chosen final content of $20 \%$ was obtained by varying the initial platicizer/protein ratio between 0.56 (EG) and 0.26 (GLY) (Table 3). Except for EG and TEEG, no significant difference of plasticizer content was observed. The water contents were similar except with TEG, for which it was lower. A lower water content is expected to decrease plasticity (Baumberger et al., 1997), because water also acts like a plasticizer.

The mechanical properties of films with the same amounts of residual plasticizer are shown in Table 3. Considering the series of plasticizers EG-TEEG, TS values were similar for EG and DEG and higher for TEG. In contrast, TEEG resulted in lower TS. EL increased when the chain length increased. TEG yielded EL lower than expected, not significantly different from EG and DEG; however, the TEG content in film was lower, too. GLY provided properties similar to TEEG, that is, the greatest EL and the lowest TS in the series. Expressing the TS and EL versus the molar concentration of plasticizers did not abolish the differences among plasticizers (not shown), in opposition to results obtained on fish myofibrillar proteins (Cuq et al., 1997b). The results on gliadin films were different, too, from what was reported on pea proteins by Guéguen et al. (1998), that is, decreased EL and TS of films with increased plasticizer chain length. This probably arises from the specific structures and properties of pea globulins and wheat prolamins, leading to different behaviors in the presence of plasticizers. In the case of wheat gliadin, it appeared that TEEG and glycerol had a higher "plasticizing activity" than other plasticizers tested.

The surface properties of films are shown in Table 3. The high values of contact angles confirmed the results reported above. TEEG, the plasticizer with the longest carbon chain, provided the highest contact angle. Globally, the contact angles were similar to those obtained for methylcelullose-paraffin wax films (Martin Polo et al., 1992). However, as stated previously, this surface analysis should be completed in the future by kinetic studies to characterize in more detail the wetting of films.

Effect of Plasticizer Concentration. Films were prepared with final concentrations of plasticizer in the range of 14-20\% for DEG and 10-15\% for DEGMET. Water contents of films showed variations that were not linked to the amount of plasticizer (not shown). The mechanical properties at the different plasticizer concentrations are shown in Table 4. A decrease of TS and an increase of EL were observed when the concentration of DEG or DEGMET increased. By small changes of the plasticizer concentrations in gliadin films, it was therefore possible to modify considerably their mechanical properties. The amplitude of variation of TS was wider with DEGMET, but this may be due to the lower concentrations studied. Such concentration-dependent properties were expected in the case of plasticizing molecules. The same were described with different plasticizers for films of zein, a maize prolamin (Park et al., 1994), and of fish myofibrillar proteins (Cuq et al., 1997a) but, once again, gliadin films opposed to pea protein films, for which increasing DEG concentration resulted in reduced EL (Guéguen et al., 1995).

Contact angles were high and similar for both plasticizers (Table 4), as previously mentioned. They did not follow the variations of DEG or DEGMET concentrations, and the more hydrophobic DEGMET did not induce larger angles. This suggested that surface hydrophobicity of gliadin films arose from the properties of the constituting proteins and was not much influenced by the type and the plasticizer contents.

Relationship between TS and EL of Films. Different plasticizers were used in this study. All data on mechanical properties were tentatively combined in a synthetic plot showing EL versus log TS (Figure 3). The best fit was obtained with a linear model. The coefficient of correlation was -0.97 , which indicated a strong 


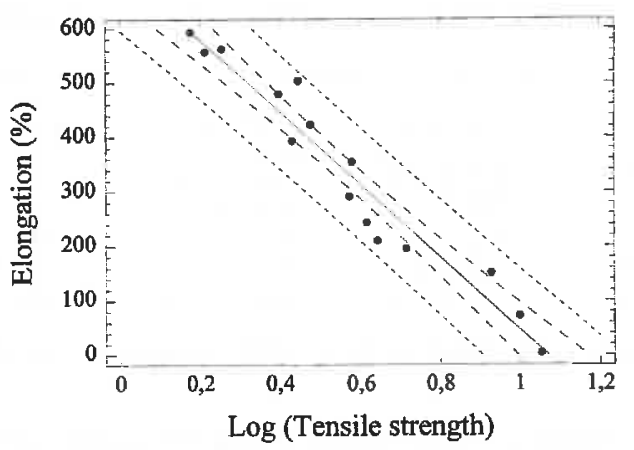

Figure 3. Plot of the best fit for EL versus log TS of gliadin films prepared with glycerol and different polyols of the ethylene glycol series. Coefficient of correlation was -0.97 .

relationship between the variables. The analysis of variance indicated it was significant at the $99 \%$ confidence level. This suggested the relationship between strain and stress of gliadin films is independent of the chemical structure of the plasticizer molecule incorporated in the film. This plot indicates that, regardless of plasticizer type, limit values of elongation at break and maximum strength of gliadin films will be about $700 \%$ versus $1 \mathrm{MPa}$ and $0 \%$ versus $11 \mathrm{MPa}$, respectively. With the plasticizers studied here, the molecule structure influenced film properties by determining the amount required to obtain a given plasticization. This is expected if no specific interaction occurs between protein and plasticizer. Volatility of plasticizers affects their residual concentrations in films and the stability of films with aging.

The mechanical properties measured with gluten films prepared under alkaline conditions (Gennadios et al., 1993b,d) fell in the range of those recorded here with gliadins films. A direct comparison was prevented by conditions of mechanical testing (differing specimen shapes and cross-head speeds).

Conclusion. An alkaline casting process, excluding alcohol, was found to be convenient to prepare gliadin films. It yielded homogeneous solutions with the required viscosity for casting. Adjusting the plasticizer concentration in films led to a wide range of elongation values. This made gliadin an interesting alternative raw material for making films. However, it was not possible to reach TS values as high as those of lowdensity polyethylene with similar elongations, 8.6-17.3 MPa (Gennadios et al., 1993b). TS and EL of gliadin films were linked by a negative relationship. Changing the plasticizer modified the residual content of plasticizer in films but not the TS/EL relationship. Thus, the least volatile plasticizers are recommended, because the control of their concentration in films is easier and they ensure more constant properties with aging. In this study, tetraethylene glycol was more convenient than other polyols of the ethylene glycol series compared, because the loss during film drying was limited and it was more efficient at smaller concentrations. Glycerol resulted in similar film properties as tetraethylene glycol, except that the viscosity of film-forming solutions was then considerably higher. This offers a possibility to adapt the properties of the film-forming solution to the casting conditions.

\section{ACKNOWLEDGMENT}

We thank J. Barbot for technical assistance and advice.

\section{LITERATURE CITED}

Ali, Y.; Ghorpade, V. M.; Hanna, M. A. Properties of thermallytreated wheat gluten films. Ind. Crops Prod. 1997, 6, 177184.

Banker, G. S. Film coating theory and practice. J. Pharmacol. Sci. 1966, 55, 81-89.

Baumberger, S.; Lapierre, C.; Monties, B.; Lourdin, D.; Colonna, P. Preparation and properties of thermally moulded and cast lignosulfonates-starch blends. Ind. Crops Prod. 1997, 6, 253-258.

Bérot, S.; Gautier, S.; Nicolas, M.; Godon, B.; Popineau, Y. Pilot scale preparation of wheat gluten protein fractions IInfluence of process parameters on their protein composition. Int. J. Food Sci. Technol. 1994, 29, 489-502.

Buffo, R. A.; Weller, C. L.; Gennadios, A. Films from laboratory-extracted sorghum kafirin. Cereal Chem. 1997, 74, 473-475.

Cherian, G.; Gennadios, A.; Weller, C. L.; Chinachoti, P. Thermomechanical behavior of wheat gluten films: effect of sucrose, glycerin and sorbitol. Cereal Chem. 1995, 72, $1-6$.

Cuq, B.; Aymard, C.; Cuq, J. L.; Guilbert, S. Edible packaging films based on fish myofibrillar proteins: formulation and functional properties. J. Food Sci. 1995, 60, 1369-1374.

Cuq, B.; Gontard, N.; Cuq, J. L.; Guilbert, S. Functional properties of myofibrillar protein-based biopackaging as affected by film thickness. J. Food Sci. 1996, 61, 580-584.

Cuq, B.; Gontard, N.; Aymard, C.; Guilbert, S. Relative humidity and temperature effects on mechanical and water vapor barrier properties of myofibrillar protein-based films. Polym. Gels Networks 1997a, 5, 1-15.

Cuq, B.; Gontard, N.; Cuq, J. L.; Guilbert, S. Selected functional properties of fish myofibrillar protein-based films as affected by hydrophilic plasticizers. J. Agric. Food Chem. $1997 \mathrm{~b}, 45,622-626$.

Extrand, C. W.; Kumagai, Y. An experimental study of contact angle hysteresis. J. Colloids Interface Sci. 1997, 191, 378383.

Gennadios, A; Weller, C. L. Edible films and coatings from wheat and corn proteins. Food Technol. 1990, 44 (10), 6369.

Gennadios, A.; Weller, C. L. Edible films and coatings from soymilk and soy protein. Cereal Foods World 1991, 36, 1004-1009.

Gennadios, A.; Park, H. J.; Weller, C. L. Relative humidity and temperature effects on tensile strength of edible protein and cellulose ether films. Trans. ASAE 1993a, 36, 18671872.

Gennadios, A.; Brandenburg, A. H.; Weller, C. L.; Testin, R. F. Effect of $\mathrm{pH}$ on properties of wheat gluten and soy protein isolate films. J. Agric. Food Chem. 1993b, 41, 1835-1839.

Gennadios, A.; Weller, C. L.; Testin, R. F. Modification of physical and barrier properties of edible wheat gluten-based films. Cereal Chem. 1993c, 70, 426-429.

Gennadios, A.; Weller, C. L.; Testin, R. F. Property modification of edible, wheat gluten-based films. Trans. ASAE 1993d, 36, 465-470.

Gennadios, A.; Hanna, M. A.; Kurth, L. B. Application of edible coatings on meats, poultry and seafoods: a review. Lebensm. Wiss. -Technol. 1997, 30, 337-350.

Gontard, N. Films et enrobages comestibles: étude et amélioration des propriétés filmogènes du gluten. Sc.D. thesis, Université de Montpellier, France, 1991.

Gontard, N.; Ring, S. Edible wheat gluten film: influence of water content on glass transition temperature. J. Agric. Food Chem. 1996, 44, 3474-3478.

Gontard, N.; Guilbert, S.; Cuq, J. L. Edible wheat gluten films: influence of the main process variables on film properties using response surface methodology. J. Food Sci. 1992, 57, 190-195.

Gontard, N.; Guilbert, S.; Cuq, J. L. Water and glycerol as plasticizers affect mechanical and water vapor barrier properties of an edible wheat gluten film. J. Food Sci. 1993, $58,206-211$. 
Guéguen, J.; Viroben, G.; Barbot, J. Preparation and characterization of films from pea protein isolates. Proceedings of the 2nd European Conference on Grain Legumes; AEP: Paris, 1995; pp 358-359.

Guéguen, J.; Viroben, G.; Noireaux, P.; Subirade, M. Influence of plasticizers and treatments on the properties of films from pea proteins. Ind. Crops Prod. 1998, 7, 149-157.

Herald, T. J.; Gnanasambandam, R.; McGuire, B. H.; Hachmeister, K. A. Degradable wheat gluten films: preparation, properties and applications. J. Food Sci. 1995, 60, 1147$1150,1156$.

Kester, J. J.; Fennema, O. R. Edible films and coatings: a review. Food Technol. 1986, 40 (12), 47-59.

Krochta, J. M.; De Mulder-Johnston, C. Edible and biodegradable polymer films: challenges and opportunities. Food Technol. 1997, 51 (2), 61-74.

Kunte, L. A.; Gennadios, A.; Cuppett, S. L.; Hanna, M. A.; Weller, C. L. Cast films from soy protein isolates and fractions. Cereal Chem. 1997, 74, 115-118.

Marquié, C.; Aymard, C.; Cuq, J. L.; Guilbert, S. Biodegradable packaging made from cottonseed flour: formation and improvement by chemical treatments with gossypol, formaldehyde and glutaraldehyde. J. Agric. Food Chem. 1995, 43, 2762-2767.

Martin Polo, M.; Mauguin, C.; Voilley, A. Hydrophobic films and their efficiency against moisture transfer. 1 . Influence of the film preparation technique. J. Agric. Food Chem. 1992, 40, 407-412.

Mate, J. I.; Krochta, J. M. Whey protein coating effect on the oxygen uptake of dry roasted peanuts. J. Food Sci. 1996, $61,1202-1206,1210$.

McHugh, T. H.; Krochta, J. M. Sorbitol- vs glycerol-plasticized whey protein edible films: integrated oxygen-permeability and tensile property evaluation. J. Agric. Food Chem. 1994, 42, 841-845.

McHugh, T. H.; Aujard, J. F.; Krochta, J. M. Plasticized whey protein edible films: water vapor permeability properties. J. Food Sci. 1994, 59, 416-419.

Miller, K. S.; Krotcha, J. M. Oxygen and aroma barrier properties of edible films: A review. Trends Food Sci. Technol. 1997, 8, 228-237.
Okamoto, S. Factors affecting protein film formation. Cereal Foods World 1978, 23, 256-262.

Park, H. J.; Bunn, J. M.; Weller, C. L.; Vergano, P. J.; Testin, R. F. Water vapor permeability and mechanical properties of grain protein-based films as affected by mixtures of polyethylene glycol and glycerin plasticizers. Trans. ASAE $1994,37,1281-1285$.

Parris, N.; Coffin, D. R. Composition factors affecting the water vapor permeability and tensile properties of hydrophilic zein films. J. Agric. Food Chem. 1997, 45, 1596-1599.

Rayas, L. M.; Hernandez, R. J.; Ng, P. K. W. Development and characterization of biodegradable/edible wheat protein films. J. Food Sci. 1997, 62, 160-162.

Stuchell, Y. M.; Krochta, J. M. Enzymatic treatments and thermal effects on edible soy protein films. J. Food Sci. 1994, 59, 1332-1337.

Torres, J. A. Edible films and coatings from proteins. In Protein Functionality in Food Systems; Hettiarachchy, N. S., Ziegler, G. R., Eds.; Dekker: New York: 1994; pp 467-507.

Viroben, G.; Barbot, J.; Gaugain, A.; Guéguen, J. Préparation de films protéiques à partir d'isolats de pois. In Valorisations Non-alimentaires des Grandes Productions Agricoles; Guéguen, J., Ed.; INRA Editions: Paris, 1995; pp 215-218.

Yamada, K.; Takahashi, H.; Noguchi, A. Improved water resistance in edible zein films and composites for biodegradable food packaging. Int. J. Food Sci. Technol. 1995, 30, 599-608.

Received for review April 13, 1998. Revised manuscript received September 8, 1998. Accepted September 14, 1998. This research was supported by a postdoctoral grant from the Spanish Ministry of Education to A.C.S. and financed by European Union DG XII, FAIR Program CT 96 1979, Gluten Biopolymer.

JF980375S 
